\title{
Status and conservation of crocodiles in the Koshi Tappu Wildlife Reserve, eastern Nepal
}

\author{
Rajesh Kumar Goit ${ }^{1}$ \& Khadga Basnet ${ }^{2}$ \\ ${ }^{1}$ B.P. Koirala Institute of Health Sciences, Department of Physiology, Dharan, Nepal P.O. Box 7053, Kathmandu, Nepal \\ ${ }^{2}$ Central Department of Zoology, Tribhuvan University, Kirtipur, Kathmandu, Nepal \\ Email: ${ }^{1}$ goit_rajesh@yahoo.com (corresponding author), ${ }^{2}$ kbasnet@ntc.net.np
}

Date of publication (online): 26 August 2011 Date of publication (print): 26 August 2011 ISSN 0974-7907 (online) | 0974-7893 (print)

\section{Editor: Nikhil Whitaker}

\section{Manuscript details:}

Ms \# 02735

Received 29 March 201

Final received 20 June 2011

Finally accepted 13 July 2011

Citation: Goit, R.K. \& K. Basnet (2011). Status and conservation of crocodiles in the Kosh Tappu Wildlife Reserve, eastern Nepal. Journal of Threatened Taxa 3(8): 2001-2010.

Copyright: (C) Rajesh Kumar Goit \& Khadga Basnet 2011. Creative Commons Attribution 3.0 Unported License. JoTT allows unrestricted use of this article in any medium for non-profit purposes, reproduction and distribution by providing adequate credit to the authors and the source of publication.

Author Detail: RAJESH KUMAR GoIT has completed master of science in zoology (ecology) with first division from Central Department of Zoology, Tribhuvan University. Recently, he is studying master of science in human physiology in B.P. Koirala Institute of Health Sciences, Dharan, Nepal. Khadga Basnet is professor at Central Department of Zoology, Kirtipur, Kathmandu, Nepal.

Author Contribution: Field study and pape writing was done by RKG and was supervised by KB.

Acknowledgments: We thank Sanjan Bahadur Thapa and Bridhi Lal Sardar for field guidance and invaluable suggestions.

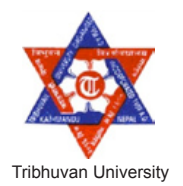

\section{(c) (i) (口)}

Abstract: Koshi Tappu Wildlife Reserve is an area of $175 \mathrm{~km}^{2}$ on the alluvial flood plains of the Koshi River in eastern Nepal. Surveys of crocodiles in the Koshi River and its surrounding areas in the reserve were conducted in winter and spring 2008 using direct observation and questionnaires besides literature reviews. Observations were done during the day using binoculars and photo shoots and sites were visited by boat, bicycle and also on foot. Although both Gavialis gangeticus and Crocodylus palustris were previously found in the reserve, only $C$. palustris was found in this study. The numbers of $C$. palustris were higher in the winter season - early January (21) than in the spring - mid March (5). The destruction and degradation of crocodiles in the reserve has been caused by various human activities such as wood collection, cattle grazing, fishing, as well as by some natural processes. The success of conservation programs depends upon awareness creation and the development of a positive attitude in the local people towards the species. During this study, most of the respondents from the local community as well as the Reserve staff were positive towards the conservation of $C$. palustris. This is important as it has its own role in the ecosystem. Continuous release and trans-boundary conservation efforts should be initiated for the protection of G. gangeticus.

Keywords: Crocodile, Crocodylus palustris, Gavialis gangeticus, Koshi River.

\section{INTRODUCTION}

Information on biodiversity such as wildlife status (abundance, distribution and home range), population and community interaction and their contribution to ecosystem development is essential (Basnet 1998). Such information is essential for conservation management of wildlife and protected areas which are developed by regular monitoring and maintaining records by various scientific methods (Basnet 1998).

The crocodiles of Nepal have attracted the attention of many herpetologists in the past. Biswas (1970) gave an account of the collection and hunting of muggers in the Koshi River. Since crocodile management commenced in Nepal, the program has maintained data on species, numbers involved and locations of release. Some 727 gharials and 164 muggers have been released from rearing stations to the wild from 1981 to 2008 (DNPWC 2008). Gharials have been successfully re-stocked into the Narayani, Babai and Karnali rivers (Andrews \& McEachern 1994). Reintroduced muggers have not been monitored (Andrews \& McEachern 1994).

A study carried out by Mishra (2002) showed that the distribution and habitat of the gharial was mainly restricted to Karnali and Babai rivers in 
Bardia National Park and Rapti and Narayani rivers of Chitwan National Park. Habitat loss has been a leading cause for Nepal's declining crocodile population. This was accelerated in the mid 1950s when an intensive malaria eradication program opened the Tarai for habitation. Intensive fishing reduced food levels and effected crocodile numbers. They become entangled in nets and either drowned or were killed by fishermen. Subsequently, tribal hunters have been collecting eggs and slaughtering crocodiles for food and medicinal purpose (Andrews \& McEachern 1994). In recent years, the construction of dams and barrages has blocked migratory routes.

During recent years, crocodile breeding has gained increasing importance. The health and disease in farmbred crocodiles have been a major concern in all parts of the world (Lal 1981). Management of crocodiles in both wild and captive conditions has attracted the attention of investigators. Recently, various techniques have been developed for their management. Shrestha (2001) gave an interesting account of management and conservation of crocodiles in Nepal. Le Foll (1982) studied zoo technical problems of muggers in Chitwan National Park.

IUCN Nepal initiated a program for muggers in 1992 in order to develop information about the status of crocodiles, which were declining due to the rapid loss of wetland habitats. However, the progress of this initiative was not made public. The recently created Wetland Inventory and Conservation Programme augments the crocodile projects by supplying logistic support and facilities.

\section{Objective}

The main objective of the study was to assess the present status of crocodiles present in the Koshi Tappu Wildlife Reserve and provide information required for management.

The specific objectives of this study were as follows:

- To estimate the population of crocodiles in the reserve

- To assess the threats associated with the crocodiles in the reserve, and

- To provide management recommendations for conservation

\section{MATERIALS AND METHODS}

A preliminary survey was conducted in KTWR from 1 to 6 November 2007 to explore the potential sites of crocodiles. Reserve staff, nature guides and local people (fishermen, cattle grazers, timber/ firewood collectors, boatmen etc.) were consulted. The detailed survey was carried out from 1 to 9 January in winter and from 15 to 20 March in spring. The survey was carried out during the daytime from 0900 to $1600 \mathrm{hr}$. Observations were made along the river and from the eastern bank. Binoculars and photos were used for observation. The presence of crocodiles in segmented areas was based on sightings as well as indirect evidence. Mugger crocodiles were categorized into size classes- $>1.5 \mathrm{~m}$ as adults, $<1.5 \mathrm{~m}$ as sub adult (Andrews 1993). In order to count the crocodile population and its signs, the study area was divided into three stretches (transects) on the basis of the main river and its branches (Image 1).

Transect I: Included the main river where the river course was deep and fast moving with wide width from Prakashpur to Kushaha, about $8 \mathrm{~km}$ in length. The riverine vegetation with Dalbergia sissoo-Acacia catech $u$ forest, dominated the western edge of the river in this area. This forest is mainly associated with Saccharum-Phragmitis grassland with other grassland species like Setaria pallidifusca, Cyperus sp., Eclipta prostrata, Alternanthera sessilis, Desmodium.

Transect II: Included the western branch of the river from Madhuban to Kushaha about $4 \mathrm{~km}$ in length. In this branch of the river the water velocity was slow. In these areas, vegetation like tall elephant grasses Imperata cylindria and Saccharum spontaneous along with scattered Dalbergia sissoo were found.

Transect III: Included the eastern branch of the river from Prakashpur to Shripur about $10 \mathrm{~km}$. The structure and vegetation of this area was the same as in Transect II.

This part also included marshy areas situated between the river and the eastern embankment of the reserve from Madhuban to Shripur. The area was wide with shallow water at the margins and deep water in the middle, with elevated patches of land. In this area, vegetation like Imperata cylindria and Saccharum spontaneous along with emergent species Fimbristyllis squarrosa, Saccharum spontaneum, Persicaria lapathifolia; floating species Nymphoides 


\section{Koshi Tappu Wildlife Reserve \& Buffer Zone}

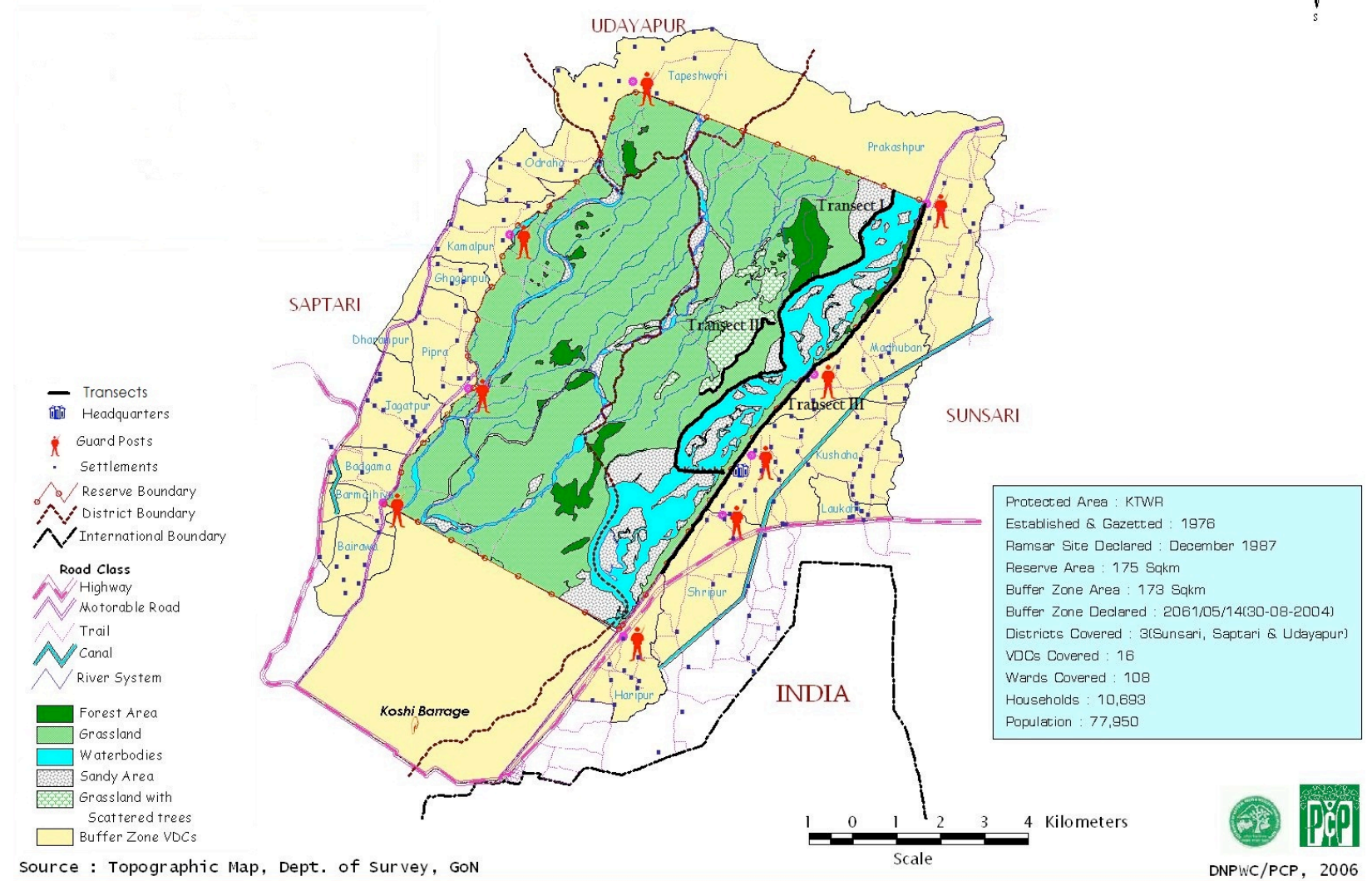

Image 1. Transects in the study area

hydrophyllum and submerged species HydrillaCeratophyllum were found profusely.

Specific river stretches (transects) were repeatedly surveyed. If animals or signs of them were seen in the same locations as previously observed, then they were classified as repeat counts. If the number was more than previously or different in size and shape than previously seen, or if the signs were found in different places, it was counted as different animals or signs. During the survey a multi-platform count was done to increase the chances of recording all the individuals and to reduce sampling biases. There were two persons deployed in each of its three potential habitats (Sixth Tower, Madhuban and Prakashpur in winter; and Kushaha, Madhuban and Prakashpur in spring). During the fixed time period, observers noted the number of individuals in each area to get less biased results. The maximum count in any one count effort on a particular site was taken as the final count unless the individual's size and shape was different than previously seen. Adults and subadults were counted on the basis of ocular estimation. If a crocodile was observed and the situation allowed, the attempt was to approach the individual as close as possible.

For indirect evidence of crocodile presence in an area, "U" shaped markings were checked. Generally crocodiles leave a " $U$ " shape on the sand bank along the riverbanks (Whitaker \& Basu 1983). The coordination of the observation of the crocodile and its signs were recorded by Garmin GPS. The coordinates were recorded as close as possible to the animal, paying attention not to scare it. Both natural and anthropogenic disturbance factors were identified by field observation, questionnaire surveys, and literature reviews.

\section{RESULTS}

A total of 21 muggers were observed which included 14 adults and seven sub adults in five different locations and eight marks of animals in winter (Table 1). In spring, only five adult muggers were observed in four different locations with 14 marks (Table 2). 
Table 1. The result of survey in winter 2008

\begin{tabular}{|c|c|c|c|c|c|c|c|}
\hline Date & Time & Number & Type & Habitat & Position & Place & \\
\hline 2 Jan & 1430 & 2 & Adult & GB & Basking & Tetriganchi Tal & \\
\hline 2 Jan & 1430 & 1 & Sub-adult & SGB & Seeking & Tetriganchi Tal & \\
\hline 3 Jan & 1100 & $1^{*+1}$ & Sub-adult & SGB & Sub-merged & Tetriganchi Tal & \\
\hline 3 Jan & 1100 & $2^{*}$ & Adult & GB & Basking & Tetriganchi Tal & \\
\hline 4 Jan & 1000 & $2^{*}$ & Adult & GB & Basking & Tetriganchi Tal & \\
\hline 4 Jan & 1500 & $2^{*}+1$ & Sub-adult & SGB & Sub-merged & Tetriganchi Tal & \\
\hline 5 Jan & 0930 & 1 & Mark & SB & Dry & Kushaha & \\
\hline 5 Jan & 1030 & 1 & Adult & SB & Basking & Sixth Tower & \\
\hline 6 Jan & 1015 & 5 & Adult & SB & Basking & Madhuban & \\
\hline 6 Jan & 1035 & 7 & Marks & SB & Fresh & Madhuban & \\
\hline 6 Jan & 1400 & $5^{*}+1$ & Adult & SB & Gaping & Madhuban & \\
\hline 6 Jan & 1400 & 1 & Sub-adult & SB & Basking & Madhuban & \\
\hline 6 Jan & 1500 & $1^{*+1}$ & Adult & SB & Seeking & Sixth Tower & \\
\hline 6 Jan & 1500 & 1 & Sub-adult & SB & Sub-merged & Sixth Tower & \\
\hline 7 Jan & 1200 & $5^{*}$ & Adult & SB & Basking & Madhuban & \\
\hline 7 Jan & 1255 & $1^{*}+2$ & Sub-Adult & SB & Basking & Madhuban & \\
\hline 7 Jan & 0200 & 1 & Adult & $\mathrm{RC}$ & Sub-merged & Prakashpur & \\
\hline 8 Jan & 1300 & 2 & Adult & SB & Gaping & Madhuban \# & $\begin{array}{l}\text { * - Repeated count; \# - River branch; } \\
\text { GB - Grass Bank: RC - River Channel: }\end{array}$ \\
\hline $8 \mathrm{Jan}$ & 1330 & 1 & Sub-adult & SB & Basking & Madhuban \# & \\
\hline
\end{tabular}

Table 2. The result of survey in spring 2008

\begin{tabular}{|c|c|c|c|c|c|c|}
\hline Date & Time & Number & Type & Habitat & Position & Place \\
\hline 18 March & 1000 & 2 & Marks & SB & Fresh & Kushaha \\
\hline 18 March & 1020 & 1 & Mark & SB & Fresh & Kushaha \\
\hline 18 March & 1110 & 2 & Marks & SB & Dry & Fifth Tower \\
\hline 18 March & 1150 & 6 & Marks & SB & Fresh & Madhuban \\
\hline 18 March & 0115 & 2 & Marks & SB & Fresh & Prakashpur \\
\hline 18 March & 0210 & 2 & Adult & SGB & Running & Madhuban \\
\hline 18 March & 0240 & 1 & Adult & SGB & Running & Kushaha \\
\hline 19 March & 1045 & $3^{*}$ & Marks & SB & Fresh & Kushaha \\
\hline 19 March & 1050 & 1 & Mark & SB & Old & Kushaha \\
\hline 19 March & 1215 & 1 & Adult & SB & Running & Madhuban \\
\hline 19 March & 0210 & $1^{*}+1$ & Adult & SGB & Running & Kushaha \\
\hline
\end{tabular}

* - Repeated count; \# - River branch; GB - Grass Bank; RC - River Channel; SGB - Sand Grass Bank; SB - Sand Bank

In both the seasons gharial was not observed. In this study marks were observed near the side where animals were observed.

\section{Field characteristics of the mugger crocodile}

Muggers were mainly observed during the basking, gaping, seeking, submerged positions on the western banks of the river and its branches and the marshes (Tetriganchi Tal) in winter; while all the muggers observed in spring were in motion (running) from the bank towards the river. Observations from a hide-out from late morning to late evening showed that most of the time muggers exhibited little or no activity (Tables $1 \& 2)$.

Muggers practiced basking on land (Images 2A,B) or in submerged positions (Image 2C) during the day. So, temperature selection (either heat seeking or heat avoidance) within available habitats was an important daily activity of the muggers. They sought shade, lying near the basking spot (Images 2D,E). The shade seeking activity started at about $1400 \mathrm{hr}$ (Table 1). At noon, the muggers were seen gaping by opening their buccal cavity to the sun for long periods (Image $2 \mathrm{~F}$ ). Field observations showed that muggers used the same 

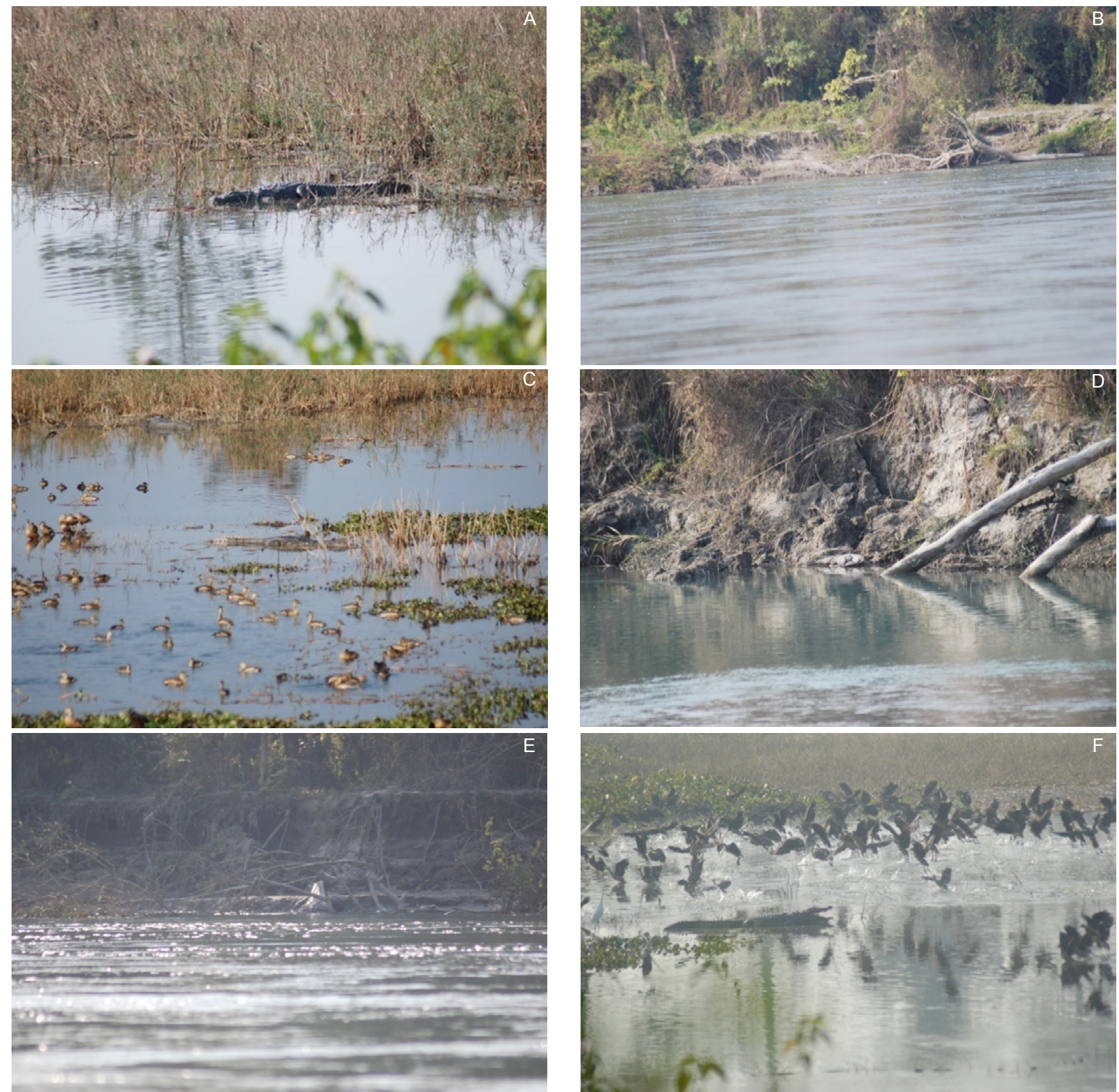

Image 2. A - An adult mugger basking on the sand grass bank; B - An adult mugger basking on the sand bank; C - An adult mugger basking on the submerged position; D - A sub adult mugger basking on the sand bank; E - A mugger seek shade lying mear the basking area; F - An adult mugger gaping on the submerged position

basking platform (Images 3A-C), finding the area by leaving a trail (Images 3D-F).

\section{Natural and anthropogenic disturbances threatening mugger}

There was very little historical information on the population of crocodiles in KTWR. So finding the factors responsible for the decreasing population of crocodiles was based on questionnaire surveys with the people of the community as well as with the Reserve staff and other crocodile experts and interested persons. The destruction and degradation of crocodiles in the reserve was caused by various human activities, as well as by some natural processes.

\section{Habitat losses}

Seepage areas on the eastern embankment adjacent to the agricultural fields were severely affected by agricultural run-off. These were hypereutrophic, being almost completely covered by Water Hyacinth 

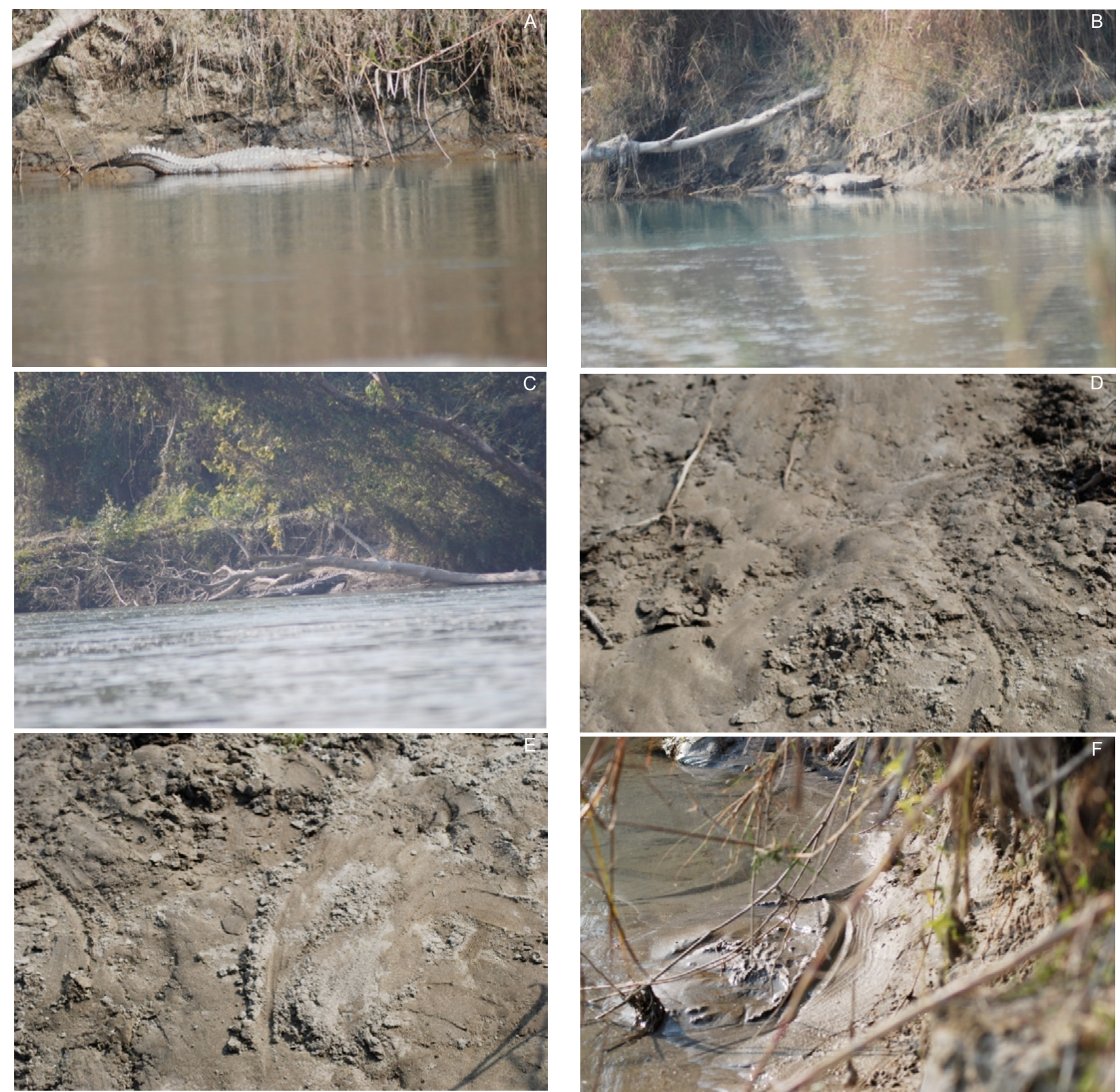

Image 3. A \& B - The mugger using the same basking platform; C - An adult mugger crawling on the sand bank; D - A mark due to its crawl; E \& F - "U" shaped marks due to its crawl

(Eichhornia crassipes) and other microphytes. Many of the wetlands had changed from mesotrophic to eutrophic due to the accumulation of nutrients from natural and human activities. So, there was only the Tetriganchi Tal as a marsh which could be used by the muggers.

\section{Barrage}

The Koshi Barrage is not equipped with devices to facilitate the migration of crocodiles. During the monsoon season strong currents of water sweep downwards most of the juvenile and released crocodiles into the Indian river systems. Downstream movement of crocodiles was also reported from the Koshi River to India. During this study one adult gharial was found in Bhimnagar (Zero kilometer), Bihar, the GPS reading was $86^{\circ} 56^{\prime} 39.7^{\prime \prime} \mathrm{E}$ and $26^{\circ} 30^{\prime} 43.9^{\prime \prime} \mathrm{N}$ where crocodiles were not recorded previously.

\section{Human activities}

Though there was a lack of conservation awareness among the local people towards the crocodile, illegal 

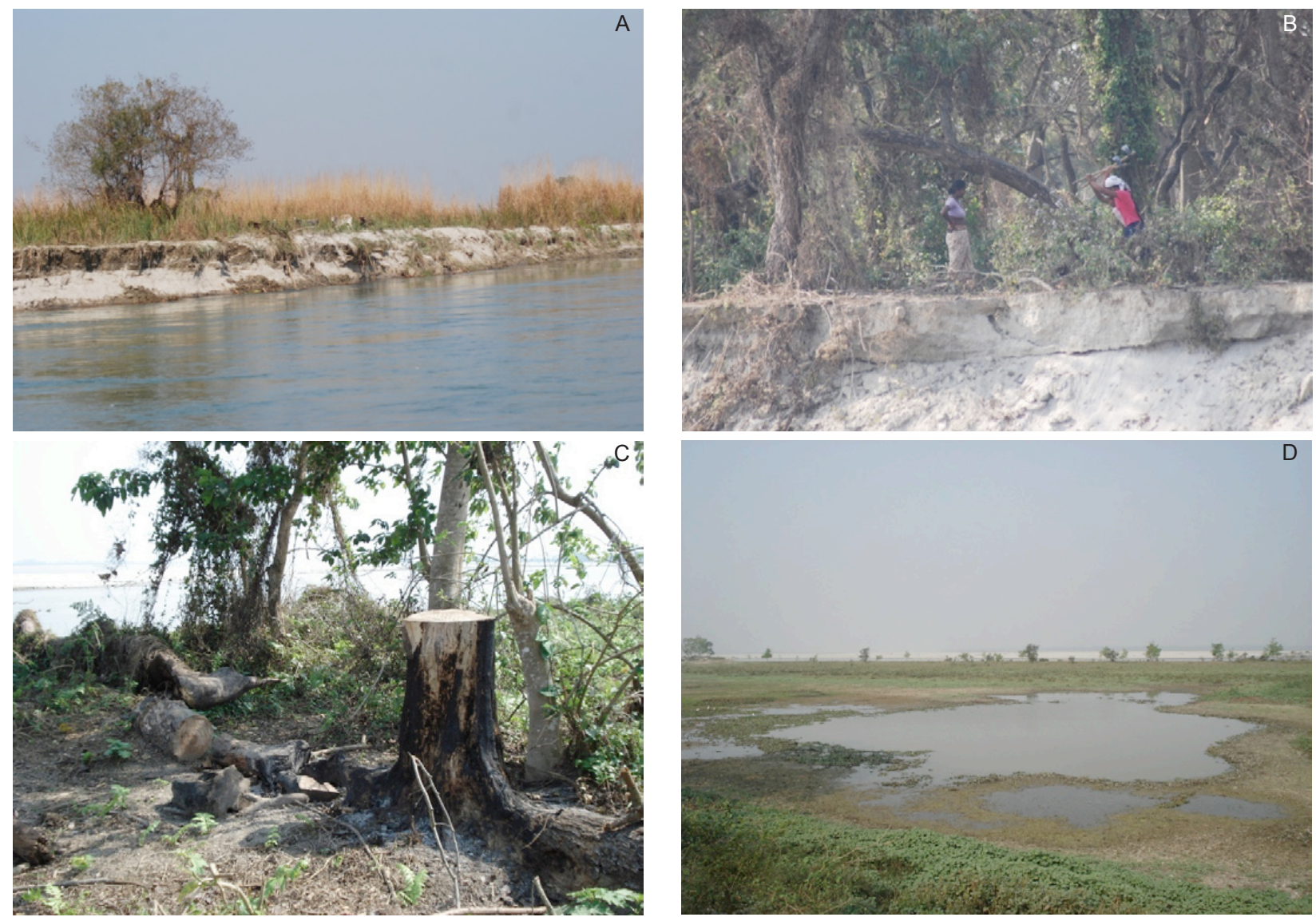

Image 4. A - Movement of the livestock along the shoreline; B - People came to collect the firewood; C - Human activities along the bank of the edge of the river; D - Low level of water in the Tetriganchital in summer

poaching was not reported in the Reserve. Since there was no clear Reserve boundary crocodiles were heavily disturbed due to human activities inside the Reserve.

Animals commonly kept by the local people were cows, buffaloes and goats. During winter, more than 30,000 animals including goats were grazed in the Reserve. Over grazing and the movement of livestock along the shoreline contributes to soil erosion which leads to the loss of suitable habitats for crocodiles (Image 4A). Village children and cattle grazers chased the muggers and disturbed them by stoning them from the dam (Tetriganchi Tal) of the Reserve when the muggers were basking.

There were no fences and no regular patrolling, people from the buffer zone and nearby villages came to the reserve illegally to collect firewood, timber, leaf litter and other forest products as well as for illegal hunting of wild animals. More than 1000 people came to the reserve for firewood for personal use or to sell in the nearby market. In the Madhuban area local inhabitants from the buffer zone of the reserve cut down trees and branches and collect the drooping branches along the riverbanks for firewood. These offer resting and holding, as well as, hiding platforms for crocodiles (Images 4B,C). In the eastern dam of the Reserve more than 1000 people came to collect firewood, timber leaf and to eat/collect bair (Zizyphus mouritiana) in winter. So the disturbances due to people walking caused stress and significant disruption in the basking activity of muggers found in the Tetriganchi Tal and the branch of the river in Madhuban. In spring more than 1000 people with permits entered to the reserve for grass cutting. Most of the areas for cutting grasses were across the river. So during this period muggers were more disturbed.

The other common activity observed in the reserve was the fishing by the indigenous community, from children to adults for subsistence living and selling. They used different techniques for fish capture, such as net, hook, traps and biological and chemical poisons but the most common method was by using 


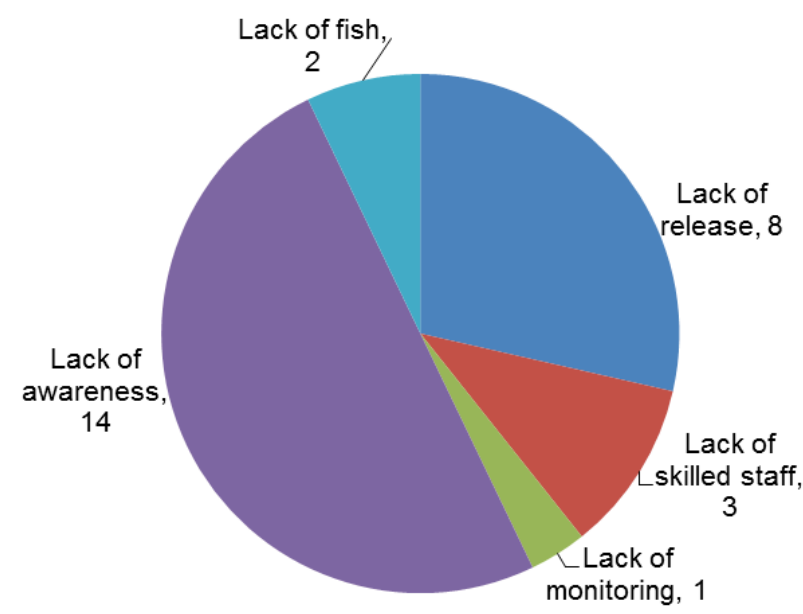

Figure 1. Responses about constrains for crocodile conservation

the net. The majority of the fish collectors were the Ghongi (including Majhi and Malah) because their poverty and limited land had driven them to do this for subsistence living. Though some had permission from headquarters, most of fishers were fishing illegally. According to the National Parks and Wildlife Conservation Act 1973 no one can hunt fish at night in protected areas, but in the Reserve it was seen that fishermen were fishing at night to sell in the markets early next morning. This type of fishing was increasing everyday and disturbed the muggers in the Reserve.

\section{Crocodile conservation and related issues}

The respondents from the local community as well as the reserve staff indicated that crocodile conservation in the Reserve was needed to save the crocodile from extinction. Lake of awareness in the community was the main obstacle for crocodile conservation in the Reserve (Fig. 1). Other factors included the lack of release of gharials in the river, regular monitoring and skilled staff.

\section{Ways of crocodile conservation}

The people of the community suggested that joint efforts for crocodile conservation would be effective, such as sharing conservation and management responsibility and incentives to the local community (Fig. 2). The financial constraints for crocodile conservation could be resolved to some extent by establishing the breeding centers in the Reserve as tourist centers. These could play a role in awareness

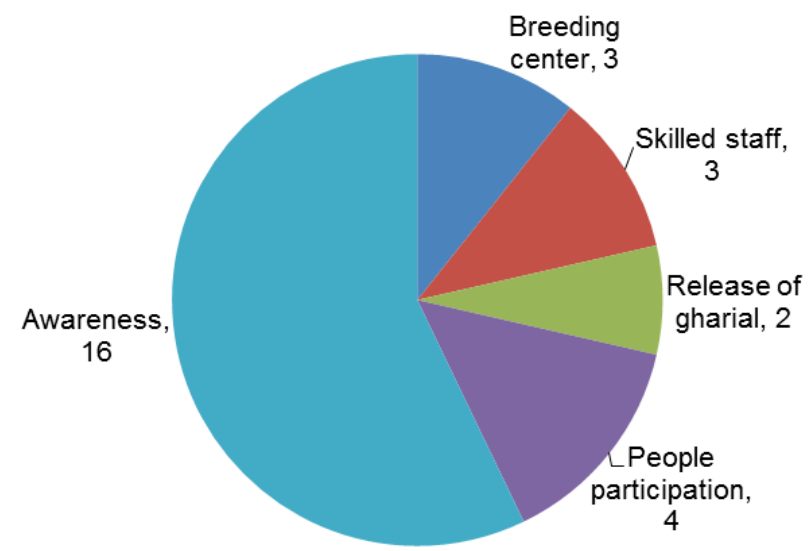

Figure 2. Conservation of crocodile according community perceptions

creation and provide extra sources of income.

People participation in crocodile conservation can be obtained by providing some alternative income with awareness creation among local ethnic groups. By identifying the hotspots of crocodiles in the river, protection of these areas could be handed over to the local communities. They could be responsible for protection, monitoring and egg collection. The Reserve should encourage the local people for participation in the protection of crocodiles.

\section{DISCUSSION AND CONCLUSION}

The only crocodilian confirmed to inhabit the Koshi Tappu Wildlife Reserve was C. palustris. There was a seasonal variation. This might be due to several reasons. First, the season for the crocodile survey was post winter and pre summer months i.e. DecemberFebruary. During this period, the temperature condition was such that the crocodiles basked for longer periods and visibility was good for sighting. This was also the courtship season and breeding groups appeared in the bank in groups (Choudhury \& Roy 1982). Second, in spring both the eastern and the western branches of the river and the marshes had low levels of water. Therefore, the animals shifted from the branches of the river (Sixth Tower and Madhuban) and the marsh (Tetriganchi Tal) to the main river. Some species aestivate by remaining quiescent for days buried in mud, leaf litter or in underground burrows excavated as water levels fell (Whitaker \& Whitaker 1984). In the dry season, muggers used their burrows to avoid 
heat during the daytime but at night they came out and wandered over the area in search of food (Mobaraki 1999). Third, crocodiles are cryptic, secretive, and historically hunted populations likely to be wary of humans (Messel, Vorlicek, Wells and Green, 1981 in William et al. 1997). Spring was followed by Kharkhadai (Grass Cutting) season (February) where people were permitted to enter the Reserve for two weeks. Most of the areas for cutting grasses were across the river. During this period mugger habitats were more disturbed and the number of individuals moved out of the study area.

In this study, the numbers of adults seen were easily comparable to the sub-adults because the movement and other activities of the subadult muggers was limited as most of the time they were hiding behind the grasses or the behind the fallen trees.

The highest population of muggers (nine) was found in Madhuban in the winter. In this region, the river course was deep and fast moving with wide width. The riverine vegetation with Dalbergia sissooAcacia catechu forest dominated on the western edge of the river. This forest was mainly associated with Saccharum-Phragmitis grassland with other grassland species like Setaria pallidifusca, Cyperus sp., Eclipta prostrata, Alternanthera sessilis, Desmodium sp., which provided a secure shelter to muggers during its seeking, hiding and sometimes resting on submerged tree trunks.

The second highest population (five) was found in the marsh area (locally known as Tetriganchi Tal) situated along the eastern embankment of the Reserve between Kushaha and Shripur. This area was wide with shallow water at the margin and deep water in the middle with elevated patches of land which helped the mugger in its daily activities. This area had adequate fish, mollusks and arthropods which were used as food. In this area, vegetation like Imperata cylindrica and Saccharum spontaneum along with emergent species Fimbristyllis squarrosa, Saccharum spontaneum, Persicaria lapathifolia floating species Nymphoides hydrophyllum and submerged species Hydrilla ceratophyllum were found profusely. This area was also dominated by a large number of wetlands birds. Among them Anser anser, Anser indicus, Dendro cygnajavanica, Tadorna ferruginea, Tadorna tadorna, Anas strepera, Anas falcata, Anas penelope, Anas platyrhynchos dominated. In the spring muggers migrated to the main river due to the low level of water in the marshes (Image 4D).

The third highest number were found in the Sixth Tower and the Madhuban. Both these are branches of the main river. In these areas, vegetation was composed of tall elephant grasses Imperata cylindria and Saccharum spontaneum along with scattered Dalbergia sissoo.

In winter most sightings were in the sand bank as compared to the other habitats. Most of the animals were found during basking and gaping. According to Whitaker \& Basu (1983), gaping has possible significance in the thermoregulation. It is perhaps a device to rid the oral cavity of infection, algae, bacteria, fungus and other pathogens and parasites. Gaping probably has other functions as well (for example a social signal), because it also occurs in the rain and at night (Loveridge 1984; Lang 1987).

Though two batches of captive gharials (42/43) were released in the Koshi River in 1983 and 1986 respectively, no animal was sighted in the study. Generally released juvenile gharials are highly mobile and very sensitive to external disturbances. Since the Koshi River originates from the high Himalaya and has very high water velocity, it may escalate the downstream mobility of juvenile and young gharials after release in the wild. Downstream movement of crocodiles during the monsoon period has also been reported from the Koshi River to the Ganges River in India (Biswas 1970). The presence of dams allows downstream movement but obstructs upstream movement of the gharials. If collaboration with the Indian Government for mutual aquatic faunal conservation is effective then it might be possible to bring back the animal to the Reserve. Reintroduction of gharial in the river is needed because releasing young gharials has become the only way to improve its distribution.

The constraints for crocodile conservation can be solved to some extent by joint efforts such as sharing conservation and management responsibility and economic incentives to the local community. People's participation in conservation of crocodiles can be obtained by providing some alternative income along with awareness creation among the local people. By identifying the hotspots of crocodiles in the river, protection of these areas could be handed over to the local communities. They should be responsible for 
protection, monitoring and egg collection. The reserve should encourage the local people to participate in the protection of crocodiles.

The crocodiles can be an attraction of visitors and create employment opportunities for the local community. The revenue collected through tourism may contribute to effective conservation. Eco-tourism may be a good solution for involving people with their traditional knowledge about crocodile conservation and will be helpful to uplift the local socio-economic conditions.

\section{CONCLUSION}

This study explored the population and distribution of crocodiles, identified the threats associated and mapped out its potential habitat in the KTWR. The only crocodilian confirmed to inhabit the reserve was C. palustris. We recorded 21 muggers in winter but only five in spring. The muggers were observed in the main river and its branches between the Prakashpur and Kushaha and Tetriganchi Tal (the marsh area) in Shripur of the reserve. Muggers were observed during the basking, gaping, seeking and submerged positions on the banks of the river and the marshes as well as running from the bank towards the river. They preferred mainly sand bank over grass bank, sand grass bank and river channels as their habitat in winter. They were found only on sand grass bank and sand bank in spring.

The Koshi River has been subjected to severe natural and anthropogenic stresses causing pronounced habitat degradation in the reserve. Siltation of river beds during the monsoons, high water velocity of swift current during floods, and change of mesotrophic marshes to eutrophic marshes are the natural factors for the low survival and sighting of crocodiles in the Koshi River. Fishing, firewood collection and grazing significantly disturbed the habitat in the Reserve. Downward movement of crocodiles during the monsoon period has been reported from Koshi River to Bihar (India) because one Gharial was seen in the marshes in Bhimnagar (Bihar) where there was no previous record.

\section{REFERENCES}

Andrews, H.V. (1993). Status and Distribution of the Mugger Crocodile in Tamil Nadu. $<$ http://wiienvis.nic.in/crocodile/ tnadu.htm>. Downloaded on 20 June 2011.

Andrews, H.V. \& P. McEachern (1994). Crocodile Conservation in Nepal. IUCN Nepal and USAID NGO Environmental Management Programme, 1-29pp.

Basnet, K. (1998). Biodiversity Inventory of Shey Phoksundo National Park. Wildlife Component. WWF Nepal, Kathmandu, 49pp.

Biswas, S. (1970). A preliminary survey of the gharial in the Kosi River. Indian Forester 96(9): 705-710.

Choudhury, B.C. \& R.K. Roy (1982). Status Survey of Crocodile Populations. A field Guide. Central Crocodile Breeding and Management Training Institute. Hyderabad, Andra Pradesh, India, 44-48pp.

DNPWC. (2008). Department of National Parks and Wildlife Conservation. Annual Report. Kathmandu, Nepal.

Lal, S. (1981). Release of gharial in natural habitat. Cheetal 23: $29-32$.

Lang, W. (1987). Crocodilian Behaviour: Implications for Management, pp. 278-286. In: Webb, J.W.G., S.C. Manolis \& J.W. Peter (eds.). Wildlife Management: Crocodiles and Alligators. Surrey Beatty and Sons Pty Limited, Australia.

Le Foll, P. (1982). Report of Zootechnical and Pathological Problems of Gharial in Gharial Project (Royal Chitwan National Park, Nepal). Eclole Natinale Venterinaire, France, $7 \mathrm{pp}$.

Mishra, N. (2002). Status and distribution of Gharial (Gavialis gangeticus) in Nepal. MSc Thesis. Department of Natural Resources and Sustainable Agriculture. Agriculture University of Norway.

Mobaraki, A. (1999). Crocodile: Their Ecology Management and Conservation. Tehran, Iran. IUCN Newsletter Crocodile Specialist Group 18: 17.

Shrestha, T.K. (2001). Herpetology of Nepal: A Field Guide to Amphibians and Reptiles of Trans-Himalayan Region of Asia. Bimla Shrestha. Kathmandu, Nepal, 200pp.

Whitaker, R. \& D. Basu (1983). The Gharial (Gavialis gangeticus): A review. Journal of the Bombay Natural History Society 79: 531-548.

Whitaker, R. \& Z. Whitaker (1984). Reproductive biology of the Mugger (Crocodilus palustris). Journal of the Bombay Natural History Society 81: 317.

William S., L. Nachar, A. Mauric, S. Settle \& D. Marsh (1997). A search for Estuarine Crocodile at Tarutao National Park, Thailand. Tiger Paper 24(3): 23. 